\title{
Future of Youth Justice in Japan
}

Masahiro Suzuki ${ }^{1}$; Kenji Takeuchi ${ }^{2}$

${ }^{1}$ School of Criminology and Criminal Justice, Griffith University, Brisbane, Australia

${ }^{2}$ Faculty of Law, Kyushu University, Fukuoka, Japan

\section{Corresponding Author}

Name: Masahiro Suzuki

Position: Doctoral candidate

Affiliation: School of Criminology and Criminal Justice, Griffith University, Brisbane, Australia

Tel: +61 (0)7 37351202

Email: masahiro.suzuki@griffithuni.edu.au

Published in Youth Justice, doi: 10.1177/1473225419869988. 


\begin{abstract}
Japanese youth justice has experienced several reforms to date. Currently, a radical revision is under consideration: to lower the age of criminal majority from 20 years to 18 years. Japanese scholars and practitioners have since been engaged in debates over this proposal. Drawing on existing empirical research on youth offending and juvenile justice, the purpose of this paper is to advance a critical analysis on (in)appropriateness of lowering the age of criminal majority. By focusing on its potential consequences, we also discuss what the future of youth justice in Japan would look like. We conclude with offering research implications.
\end{abstract}

\title{
Keywords
}

Youth justice, Japan, age of criminal majority, juvenile law, youth offending 


\section{Introduction}

The age of criminal majority varies between countries. For example, according to Abrams, Jordan, and Montero (2018; also see Pruin and Dünkel, 2015 for other countries in Europe, and Thomas, 2017 for the US), who recently examined what defines as young offenders in the justice systems of Argentina, Belize, UK, and Finland, the age of criminal majority ranges from 16 years to 21 years. In Japan, since its enactment in 1948, the Juvenile Law defines the age of criminal majority as under 20 years. The Japanese government is currently considering revising this threshold. It proposes to lower the age of criminal majority from 20 years to 18 years (Ellis and Kyo, 2017). This proposal has caused a heated debate over its justification and appropriateness. Specifically, Japanese scholars and lawyers have raised grave concerns about this radical change (Japan Federation of Bar Associations, 2015; 2018; 2019; Japanese Criminal Law Scholars, 2015; 2018; The Japanese Society of Psychiatry and Neurology, 2019).

We aim to add to this debate in Japan. By drawing on existing empirical research on juvenile justice and youth offending, our objective is to conduct a critical analysis on lowering the age of criminal majority in Japan. Inspired by Haines and Case (2018), with a focus on its potential consequences, we also discuss what the future of youth justice in Japan would look like if the age of criminal majority were lowered.

Similar to other East Asian countries, such as China (Hebenton and Jou, 2010), criminology is a subfield of law in Japan (Konishi, 2013). Most criminologists in Japan have a law background. Legal perspectives tend to dominate the debates on lowering the age of criminal majority in Japan. There is a lack of focus on important and relevant perspectives, such as developmental psychology and other behavioural and social sciences, including criminology. Examining potential consequences on the basis of existing evidence on youth 
offending and juvenile justice will offer an important contribution to advancing the discussion over revising the threshold of the age of criminal majority in Japan.

In the youth justice literature, defining the age threshold for the juvenile justice system has been a major topic of discussion (e.g. McDiarmid, 2013). For example, researchers have argued the necessity of raising the minimum age of criminal responsibility in the UK (Goldson, 2013) and Australia (Cunneen, 2017), and the 'raise the age' movement has been occurring in the US (Cauffman et al., 2017). Internationally, youth justice scholars and practitioners have advocated for expanding the scope of juvenile justice. With the proposed reform to lower the age of criminal majority from 20 years to 18 years, Japanese youth justice attempts to narrow down its scope. In this sense, discussing Japanese youth justice adds to the youth justice literature as an interesting example in the international context.

The structure of this paper is as follows. First, we briefly describe the history of reforms in Japanese youth justice, as well as the current proposed revision. Second, we provide the debates over lowering the age of criminal majority in Japan. In particular, we introduce the pros and cons that have been offered in Japanese literature. Third, drawing on existing empirical research on youth offending and juvenile justice, we critically analyse the (in)appropriateness and potential consequences of lowering the age of criminal majority. Finally, we conclude by discussing the future of youth justice in Japan and by providing future research implications.

\section{Reforms of Youth Justice in Japan}

\section{History of Reforms}

Japanese youth justice has experienced several reforms. These revisions have already been discussed elsewhere (for example, see Ellis and Kyo, 2017; Suzuki and Otani, 2017), and these past revisions are not the main focus of this paper. Therefore, we briefly review the 
history of reforms in youth justice in Japan. The Japanese Juvenile Law has been revised four times to date. Below we describe the main changes of each revision.

The first revision of the Juvenile Law in Japan occurred in 2000. This involved the following three main changes (Hoffmann, 2007; Schwarzenegger, 2003; Yoshida, 2003). First, the minimum age of criminal responsibility was lowered from 16 years to 14 years, and serious crimes, such as intentional homicide, were determined to be automatically transferred to the adult court. Second, this revision introduced a panel of judges in youth justice and enabled the involvement of prosecutors in the adjudication process of the Family Court for serious cases. Finally, victims were allowed to access the court records and offer their statements to the youth justice proceedings.

In 2007, the second revision of the Juvenile Law was conducted. Several changes were made at this time (Osaki, 2017; Takumi, 2017). These included the expansion of police investigations on status offences; lowering the minimum age for juvenile reformatory schools from over 14 years to around over 12 years; introduction of more penalties for a breach of a probation order; and the introduction of court-assigned counsel for serious crimes committed by a young offender.

The Juvenile Law in Japan was again changed in 2008. This revision mainly concerned with victim rights (Matsui, 2011). In relation to the 2000 revision on access to court records and victim statements, victim rights were expanded and strengthened. Further, victims were allowed to participate in the Family Court hearings.

The fourth and most recent revision was conducted in 2014. This revision was mainly related to sentencing (Ellis and Kyo, 2017). For example, the upper limit for custodial sentences was increased from 15 years to 20 years. The condition of parole was also tightened so that it required a longer period before eligibility. 
The Juvenile Law in Japan has been revised as discussed above. The common theme among these reforms is that it was revised in a punitive way (Kuzuno, 2005). Inconsistent with the aim of the Juvenile law — to protect juveniles - young offenders, particularly those who commit a serious crime, now receive more severe punishments. As Suzuki and Otani (2017, p. 168) noted, 'the notion of parens patriae, long maintained in the Japanese youth justice, seems to be declining'.

\section{The Current Proposed Revision}

In addition to these past reforms, another revision is currently under consideration. The Japanese government proposes to lower the age of criminal majority from 20 years to 18 years. This proposal is not entirely new. Since the enactment of the current Juvenile Law, lowering the age of criminal majority has been advocated several times, particularly by prosecutors in the 1960s and1970s. However, it was never implemented because its justification that youth crime was worsening was found to be wrong during the legislative council that discussed this proposal (Saito, 2018; Takeuchi, 2017b). We elaborate on two main reasons why this revision is again proposed.

The first and foremost reason is the revision of the Public Offices Election Law (Japanese Ministry of Justice, 2016; Osaki, 2017; Takumi, 2017). In 2015, the right to vote was lowered from 20 years to 18 years. The supplementary provision of this revised law required legislators to consider also revising the civil law because the civil law in Japan defines 20 years as an adult, which was the reason why the right to vote was set at 20 . This provision also requested legislators to take other necessary legislative measures. As a result, the Japanese government has started considering lowering the age of criminal majority from 20 years to 18 years to maintain consistency among laws.

Another reason for this proposal is the tough on (youth) crime policy (Japanese Criminal Law Scholars, 2015; Kawade, 2015; Sasaki, 2016). The most apparent example is the remark 
by the then Chairperson of the Policy Research Council in the ruling party, the Liberal Democracy Party of Japan, that it is necessary to consider revising the Juvenile Law in order to address the increasingly serious nature of youth offending. As is evident in the past reforms of youth justice in Japan (Fenwick, 2013; Ryan, 2005), lowering the age of criminal majority in Japan is proposed as part of increasing punitiveness in the Japanese criminal justice policy (Fenwick, 2013; Hamai and Ellis, 2008; Miyazawa, 2008).

\section{Debates over Lowering the Age of Criminal Majority in Japan}

The proposal of lowering the age of criminal majority in Japan has caused a heated debate among scholars and practitioners in youth justice. Once it is approved, it will be arguably one of the most radical revisions to transform Japanese youth justice, in the sense of who qualifies as 'youth' offenders. In this section, we introduce the debates over lowering the age of criminal majority in Japan. We focus on the pros and cons that have been offered in Japanese literature.

\section{Pros}

To discuss the proposal of lowering the age of criminal majority in Japan, the Japanese Ministry of Justice has formed a study group consisting of scholars and government officials (Japanese Ministry of Justice, 2016). This study group interviewed experts involved in youth justice and juvenile law, lawyers, victim support groups and media, and sought public opinions and examined current juvenile justice and youth offending in Japan. Subsequently, it published a report summarising the overall discussion. As some scholars, such as Takumi (2017) and Osaki (2017) observed, this report outlines reasons for justifying lowering the age of criminal majority in Japan (Japanese Ministry of Justice, 2016).

The major reason for its justification is to maintain consistency with other laws (Japanese Ministry of Justice, 2016). As discussed above, as a consequence of the revision of the right 
to vote in the Public Offices Election Law, other laws, such as the civil law, will also redefine an adult as 18 years. The advocates of lowering the age of criminal majority argue that people over 18 years who are considered adults in the civil law should not be eligible for the Juvenile Law in terms of the notion of parens patriae. In light of paternalism that governs the criminal justice system in Japan (c.f. Foote, 1992), it is considered that those who are defined as an adult should not receive protection of the Juvenile Law as children (see also a discussion in the legislative council of the Japanese Ministry of Justice, Hoseishingikai, 2018). They also suggest that consistency between laws would help to promote understanding among the public in terms of the legal definition of an adult in Japan. They claim that it is important to raise the awareness of and hold accountable young people who are above 18 as an adult in the criminal justice system. To strengthen this argument, the advocates provide examples of other countries that define 18 years as an adult offender (Japanese Ministry of Justice, 2016).

In addition to these reasons, the advocates of lowering the age of criminal majority claim that increased recidivism as a potential consequence of lowering the age of criminal majority can be addressed by taking new measures for young adult offenders aged 18-19 years (Japanese Ministry of Justice, 2016). For example, they suggest introducing a new punishment that allows young adult offenders to be accommodated in juvenile reformatory schools, or new rehabilitation programs that offer special treatments in the adult correction facilities. They also propose to prepare a special measure for re-entry support, such as coordination with relevant agencies for housing and employment (Japanese Ministry of Justice, 2016).

\section{Cons}

In contrast to the endorsement for lowering the age of criminal majority in Japan, there are strong criticisms against lowering the age of criminal majority in Japan. Juvenile law and 
youth justice scholars in Japan have raised grave concerns (Japan Federation of Bar Associations, 2015; 2018; Japanese Criminal Law Scholars, 2015; 2018) because the proposed revision does not align with the philosophy, history, purpose, and practice of youth justice and Juvenile Law in Japan.

Japanese scholars have offered the critique that maintaining consistency among laws cannot justify lowering the age of criminal majority because it is not consistent with the legislative intent of the Juvenile Law to protect and rehabilitate young offenders (Goto, 2015). They go on to argue that reflecting its legal purposes, different laws should be able to set different ages to define an adult (Maruyama, 2017; Saito, 2018; Takeuchi, 2017a). In fact, as Abe and Yamazaki (2018) have observed, the Japanese government plans to continue restricting access to smoking, drinking and gambling among people under 20 years. Such restrictions are reflections and evidence of paternalism, which the Japanese government considers necessary for protecting these young people who are currently eligible for the Juvenile Law (Japan Federation of Bar Associations, 2018).

Another critique is based on a historical perspective of the Juvenile Law in Japan. In the past, inconsistency between laws regarding the age of majority existed in Japan (Washino, 2017). While the civil law defined 20 years as an adult, the old Juvenile Law set the age of criminal majority as 18 years. After World War 2, when the current Juvenile Law was enacted, the age of criminal majority was raised from 18 years to 20 years (Maruyama, 2017; Moriya, 2018). It is important to note here that this revision of raising the age of criminal majority was conducted not because of the need to maintain consistency between laws. Instead, the age of criminal majority was raised because it was recognised that offenders under 20 years are still transitioning into adulthood, and therefore requiring protection because of their developmental needs (Takeuchi, 2015b). 
Japanese scholars also criticise against lowering the age of criminal majority by giving examples of other countries that define the age of criminal majority as 18 years. This is not only because there are also countries whose age of criminal majority is 21 years (Abe and Yamazaki, 2018). But also, as Takeuchi (2017b) has observed, even if the age of criminal majority is 18 years, some of these countries, such as Germany, offer special proceedings and treatment for young adult offenders aged 18-21 years because there is consensus that they are more equivalent to young offenders than adult offenders in their maturity.

The strongest criticism against lowering the age of criminal majority in Japan is derived from a rehabilitative perspective. This concern is especially raised in the event of a minor crime. According to Takeuchi (2017a) who analysed the Japanese youth justice system, minor crimes are the most common crime committed by senior young offenders who would become ineligible for the Juvenile Law after the proposed revision. Takeuchi (2017a) observed that these minor crimes, such as theft and assault, are currently handled in accordance with the aim of the Juvenile Law. Even if young offenders commit a minor crime, for which adult offenders would receive only a suspended prosecution or fine, these young offenders need to undergo a clinical assessment governed by the Family Court and receive necessary treatments. In practice, Japanese youth justice is operated with this rehabilitative focus. In this sense, youth justice in Japan is not necessarily 'soft' on youth crime (Abe and Yamazaki, 2018), as the politicians claim. However, lowering the age of criminal majority would result in these young offenders in need receiving a criminal record (Abe and Yamazaki, 2018; Japanese Criminal Law Scholars, 2018) instead of receiving appropriate treatment (Kawade, 2015; Takeuchi, 2015a). This potential consequence does not align with the purpose of the Juvenile Law - to give a second chance to young offenders (Otsuka, 2018). 


\section{(In)Appropriateness of Lowering the Age of Criminal Majority}

The preceding section has provided the current debates over lowering the age of criminal majority in Japan. In this section, we critically analyse the (in)appropriateness of lowering the age of criminal majority in Japan. To do so, we discuss whether this proposed revision of lowering the age of criminal majority in Japan is in line with established knowledge based on existing empirical research on juvenile justice and youth offending. Because the debates over lowering the age of criminal majority in Japan tend to be limited to legal perspectives, examining its potential consequences on the basis of existing empirical evidence on youth offending and juvenile justice will shed new light on the debates. We focus on the characteristics of young offenders and the potential consequences of changing the age of criminal majority.

\section{Characteristics of Young Offenders}

Evidence shows that young offenders differ from adult offenders. First, young offenders only have limited comprehensibility. The most well-known research is by Grisso (1981; Grisso et al., 2003). Examining the level of understanding of Miranda warnings, Grisso's research has demonstrated that youths younger than 15 years, or those with IQ scores below 80, have difficulties properly understanding their legal rights. This finding is consistent with the results in recent research (e.g. Eatwood et al., 2015; Zelle et al., 2015). This challenge facing young offenders is also recognised by lawyers. Interviewing attorneys in Canada, Viljoen et al. (2010) found they had faced challenges when defending juvenile offenders; they had encountered cases that made them question whether young offenders correctly understood the legal process and consequences of their decision-making. Young offenders feel this difficulty in the youth justice process. Lount et al. (2018) examined how young offenders experienced and perceived youth justice in New Zealand. Their findings 
highlighted that, due to their low verbal ability, young offenders felt disadvantaged in the justice process because they had difficulties understanding the legal terms used.

Another distinction between young and adult offenders is their level of psychosocial maturity (Cauffman and Steinberg, 2000; Steinberg and Cauffman, 1996). Young offenders have a diminished ability of judgement because they are more impulsive and often cannot consider future consequences in their decision-making. In other words, young offenders tend to be risk-takers (Steinberg, 2008) and sensation-seekers (Steinberg et al., 2008). This characteristic is evident in their decision to become involved in anti-social behaviours (Cauffman et al., 2016). Examining the effect of psychosocial maturity on antisocial decision-making, Modecki (2008, p. 88) has found that 'adolescents are less mature on the judgment ... relative to college students, young-adults, and adults'. Similar results are reported in other research (e.g. Bryan-Hancock and Casey, 2010).

Young offenders are still in the human developmental process. For this reason, young offenders need a different justice system that offers special treatment and care. This difference between young and adult offenders is the reason why the 'raise the age' movement has been occurring in the US (Cauffman et al., 2017; Justice Policy Institute, 2017; Thomas, 2017). While the age of criminal majority is 18 years in most states, in several states, such as New York (Raise the Age NY, n.d.), the age of criminal majority is still lower than 18 years (Arya, 2011). Along with this 'raise the age' movement, some states, such as Louisiana (Louisiana Youth Justice Coalition, 2016), have already successfully raised the age of criminal majority to 18 (Williams, 2015).

Several scholars have further argued that young adult offenders aged 18-24 years are more comparable to younger offenders (Cauffman, 2012; Farrington et al., 2012; Feld, 2018; Prior et al., 2011), thereby claiming that these young adult offenders should be treated similarly, or that special courts and correctional facilities should be established for them 
(Farrington et al., 2012; Loeber et al., 2012; Loomis-Gustafson, 2017). Young adult offenders tend to have the same characteristics, as well as face the same challenges in the justice procedures, as younger offenders. Examining experiences of young adult offenders (18-25 years) in the criminal justice system in Hong Kong, Cheng and Leung (2018) have found that they also faced difficulties similar to those described above, such as lack of understanding of their legal rights and of the legal process. This is congruent with the research conducted in the UK, showing that young adult offenders experienced challenges understanding the legal terminology used in the criminal justice procedure (Centre for Justice Innovation, 2018). If young offenders receive different treatment in a different justice system due to their immaturity, young adult offenders may also need such care because they may be more like young offenders than adult offenders.

In sum, given the differences between young and adult offenders, lowering the age of criminal majority from 20 years to 18 years in Japan does not align with the evidence on the characteristics of young offenders. Considering similarities between young and young adult offenders, this proposed revision is, rather, moving in the opposite direction to the evidence. It may result in young offenders losing opportunities to receive appropriate treatment, consequently leading them to reoffending.

\section{Potential Consequences of Lowering the Age of Criminal Majority}

As discussed above, one of the justifications for lowering the age of criminal majority in Japan is that the current Juvenile Law is 'soft' on youth crime. By punishing young offenders more severely, it intends to prevent youth offending. However, due to the revision in the Juvenile Law, serious youth crimes are already transferred to the adult criminal justice system in Japan. More importantly, there is no evidence that this juvenile transfer can prevent youth crime in terms of both specific and general deterrence. 
As for specific deterrence by juvenile transfer, many studies have been conducted. Therefore, there exist several systematic reviews and meta-analyses. According to the systematic review conducted by the Task Force on Community Preventive Services, the juvenile transfer is more likely to increase reoffending among transferred youths than among those not transferred (Hahn et al., 2007; McGowan et al., 2007). While the number of studies included is small, the meta-analysis conducted by the Washington State Institute for Public Policy (2014) also indicates that juvenile transfer is related to an increased likelihood of recidivism. Similarly, in the most recent meta-analysis, Zane, Welsh, and Mears (2016, p. 915) have reported that juvenile transfer may lead to 'a small but statistically nonsignificant increase in future offending'. While cautioning the interpreting of the overall finding, they have suggested that juvenile transfer 'does not result in an overall reduction in recidivism and may even increase it'. Thus, the systematic reviews on and meta-analyses of the specific deterrence effect by juvenile transfer consistently show that juvenile transfer is likely to increase recidivism or at least have no effect on preventing it.

With regards to general deterrence through juvenile transfer, because of an insufficient number of studies, neither systematic reviews nor meta-analyses has been conducted (Hahn et al., 2007; McGowan et al., 2007). However, existing research consistently shows that juvenile transfer is not likely to have a deterrent effect on youth crime. The most recent research has been conducted by Steiner et al. (2006), who examined the general deterrence effect of juvenile transfer laws in 22 states in the US. Consistent with the past few studies (Jensen and Metsger, 1994; Risler et al., 1998; Singer and McDowall, 1988), their findings have demonstrated that juvenile transfer has no impact on deterring youth crime.

Other, but limited, research has directly explored the impact of revising the age of criminal majority on youth offending. The study conducted by Fowler and Kurlychek (2018) is one such study. In this research, focusing on the fact that the age of criminal majority in 
Connecticut was raised from 16 years to 17 years in 2010, they conducted a natural experiment. Comparing 16-year-old offenders who were processed as adult offenders before the legislative change and those who were processed as young offenders after the change, they examined the recidivism in a two-year follow-up period. They found that those treated as young offenders were less likely to reoffend than those treated as adult offenders (Fowler and Kurlychek, 2018).

However, the findings of research conducted by Loeffler and Grunwald (2015) have shown otherwise. Because Illinois also raised the age of criminal majority from 17 years to 18 years in 2010, they also conducted a natural experiment. In this study, they compared the rearrest rates between 17-year-old offenders who experienced youth justice after the change and those who experienced the adult justice system before it. Their finding has demonstrated that raising the criminal majority had no impact on recidivism. This remains the case even when they considered subsamples of those 'arrested within 60 days of their 17th or 18th birthday' as well as 'those arrested within 60 days of the change in law', in order to ensure the robustness of their findings (Loeffler and Grunwald, 2015, p. 363).

In addition to these studies on the specific deterrence effect, Loeffler and Chalfin (2017) have examined the general deterrence effect of raising the age of criminal majority. They also focused on Connecticut, but they also included the data up to 2013 because in Connecticut the age of criminal majority was again raised from 17 years to 18 years in 2012 . To examine the impact of raising the age of criminal majority on the overall youth crime rate, based on the official crime data they created a hypothetical state whose youth crime rate resembled that in Connecticut before the change in the age of criminal majority in 2010. Comparing youth crime between Connecticut and this hypothetical state, they found that raising the age of criminal majority had no impact on deterring youth crime. 
The above three studies have examined the impact of raising the age of criminal majority on youth offending, not that of lowering the age of criminal majority. One may question their relevance to this paper. In our view, however, the above findings may have an important implication about lowering the age of criminal majority. ${ }^{1}$ Although it remains speculative at this stage, changing the age of criminal majority might not have an impact on youth crime. This implication may be even more important because such null effects are seen even for raising the age of criminal majority, which is a beneficial revision for young offenders.

As Loeffler and Grunwald (2015) phrased it (although their argument was about raising the age of criminal majority), this implication may be unexpected to both advocates for and opponents of lowering the age of criminal majority in Japan. If lowering the age of criminal majority did not impact on youth crime, it would not support either side of the claims. But, when considering the consequences of lowering the age of criminal majority, it is necessary to look beyond its effect on youth offending. For example, as Farrington et al. (2017) have suggested in the context of raising the age of criminal majority, lowering the age of criminal majority may lead to a loss of an opportunity for young offenders to receive appropriate treatment and rehabilitation when needed.

A related point is that lowering the age of criminal majority may also negatively influence the future of offenders, particularly in terms of employment. Particularly

\footnotetext{
${ }^{1}$ Following the 'raise the age' movement, several cost-benefit analyses have been conducted in US, and they consistently indicated that the benefits of raising the age of criminal majority would outweigh its costs (Deitch et al., 2012; Henrichson and Levshin, 2011; Hornby Zeller Associates, 2018; Independent Democratic Conference, 2016). If raising the age of criminal majority did not have an impact or only had a limited impact on youth crime in terms of both specific and general deterrence, these estimates might have overestimated its benefits because even as a conservative estimate, these cost-benefit analyse anticipated $10 \%$ reduction of recidivism (for example, see Deitch et al., 2012; Henrichson and Levshin, 2011).
} 
problematic may be a criminal record because, unlike youth justice, a record is not expunged in the adult criminal justice system. It may influence their future employment (Illinois Juvenile Justice Commission, 2013; Justice Policy Institute, 2017; Loomis-Gustafson, 2017). The negative impact of a criminal record on employment among other outcomes, such as recidivism, is well known (e.g. Denver, 2017). Indeed, existing research on juvenile transfer shows that undergoing the adult criminal justice system rather than in the youth justice system is linked to diminished opportunities for employment as well as to reduced income (Augustyn and Loughran, 2017; Sharlein, 2018; Taylor, 2015).

Another problem of lowering the age of criminal majority may be the negative consequences of accommodating younger offenders in adult correction facilities (Cauffman et al., 2017). Compared to juvenile facilities, there tend to be fewer services available for rehabilitation in adult correctional facilities (Kupchik, 2007; Ng et al., 2012). This may be problematic because the lack of support for reintegration is noted as one of the possible reasons for the increased likelihood of reoffending by juvenile transfer (Redding, 2008). Research has also shown that younger offenders incarcerated in adult prisons are more likely to be depressed (Murrie et al., 2009; Ng et al., 2011). Additionally, young offenders incarcerated in adult prisons may be more likely to be physically or sexually assaulted (Forst and Fagan, 1989; National Prison Rape Elimination Commission, 2009).

\section{The Future of Youth Justice in Japan: Promising or Precarious?}

If the age of criminal majority were lowered, what would the future of youth justice in Japan look like? According to the extant literature on youth offending and juvenile justice, we expect that it would likely be precarious rather than promising. Given the differences between young and adult offenders, lowering the age of criminal majority does not align with existing evidence on the characteristics of young offenders. Although studies on the impacts 
of changing the age of criminal majority on youth offending are limited, coupled with the research on juvenile transfer, these studies imply that lowering the age of criminal majority may be less likely to provide benefits in terms of deterring youth crime. Lowering the age of criminal majority in Japan may raise other problems, such as diminished future opportunities for employment and negative consequences of incarceration with older prisoners. Overall, based on existing evidence, we assume that lowering the age of criminal majority is more likely to bring about negative consequences for youth justice in Japan.

However, a limitation exists in our argument because the majority of empirical studies we have relied on to build our argument have been conducted in the US. There are differences between Japan and the US in terms of how the youth justice systems operate. For instance, research suggested that ethnic minorities are more likely to be transferred to the adult court in the US (Brown and Sorensen, 2013). The quantity of young offenders who are transferred to the adult court in Japan is also different from those in the US because the annual number of serious crimes that are eligible for juvenile transfer cases in Japan is much lower than that in the US (for example, see Homusogokenkyujo, 2007). There is also a distinction in terms of age thresholds for youth justice. This difference may be of particular importance because the age of criminal majority in Japan would be 18 years even if it were lowered, whereas the age of criminal majority in most US states would be 18 years even if it were raised. Given these differences, the findings of the above studies may not necessarily apply to youth offending and juvenile justice in Japan.

Despite these limitations, we strongly recommend against lowering the age of criminal majority in Japan and argue that this proposed revision will not benefit youth justice in Japan. As we have discussed, the proposal to lower the age of criminal majority in Japan has emerged mainly out of the need to maintain consistency between laws, in particular recently with the civil law, which was determined to redefine adults as 18 years (Japanese Criminal 
Law Scholars, 2018). The proponents for this revision do not carefully consider existing knowledge on youth offending and juvenile justice. Despite the past reforms driven by punitivism (Fenwick, 2013; Hamai and Ellis, 2008; Miyazawa, 2008), Japanese youth justice has maintained its rehabilitative focus and been successful in reintegrating young offenders in practice (Ellis and Kyo, 2017). The emphasis on and success of rehabilitation in youth justice are recognised even in the study group formed by the Japanese Ministry of Justice to discuss lowering the age of criminal majority (Japanese Ministry of Justice, 2016). However, lowering the age of criminal majority might be radical enough to transform youth justice in Japan into something entirely different.

Given the recent discussions in the legislative council in Japan that do not consider the knowledge we drew upon, but emphasise the importance of consistency between laws, we are pessimistic about whether the critique will be taken into account. We anticipate that lowering the age of criminal majority is likely. This will be unfortunate for youth justice in Japan. What we can and should do is examine its impact on juvenile justice and youth offending in Japan.

Compared to not only other industrialised countries but also to other East Asian countries, Japan has fewer empirical studies in criminology (for example, see Suzuki et al., 2018). The reforms in the justice system in Japan have been implemented without giving a lot of thought to whether the revisions are moving in the right direction in light of empirical knowledge on youth offending and juvenile justice. Similarly, after reforms were conducted, little research has been conducted to evaluate the effectiveness of the reforms. Japan should step out of this vicious cycle and start developing evidence-based youth justice (Haines and Case, 2018). 


\section{References}

Abe Y and Yamazaki H (2018) Shonenho tekiyonenrei no hikisage nitsuite kangaeru. Katei no Ho to Saiban 16: 57-70 (in Japanese).

Abrams L S, Jordan S P and Montero L A (2018) What is a juvenile? A cross-national comparison of youth justice systems. Youth Justice 18(2): 111-130.

Arya N (2011) Legislative victories from 2005 to 2010: Removing youth from the adult criminal justice system. Washington D.C.: Campaign for Youth Justice.

Augustyn M B and Loughran T A (2017) Juvenile waiver as a mechanism of social stratification: A focus on human capital. Criminology 55(2): 405-437.

Brown J M and Sorensen J R (2013) Race, ethnicity, gender, and waiver to adult court. Journal of Ethnicity in Criminal Justice 11(3): 181-195.

Bryan-Hancock C and Casey S (2010) Psychological maturity of at-risk juveniles, young adults and adults: Implications for the justice system. Psychiatry, Psychology and Law 17(1): 57-69.

Cauffman E (2012) Aligning justice system processing with developmental science. Criminology \& Public Policy 11(4): 751-758.

Cauffman E, Cavanagh C, Donley S and Thomas A G (2016) A developmental perspective on adolescent risk-taking and criminal behavior. In: Piquero A R (ed.), The handbook of criminological theory. Surrey, UK: Wiley-Blackwell, 100-120.

Cauffman E, Donley S and Thomas A (2017) Raising the age: Raising the issues. Criminology \& Public Policy 16(1): 73-81.

Cauffman E and Steinberg L (2000) (Im)maturity of judgment in adolescence: Why adolescents may be less culpable than adults. Behavioral Sciences and the Law 18(6): 741-760. 
Centre for Justice Innovation (2018) The voices of young adult defendants. London, UK: Centre for Justice Innovation.

Cheng K K-Y and Leung B P-Y (2018) Passing the threshold of one justice system to the next: Challenges of emerging young adults in Hong Kong's adult criminal justice process. International Journal of Offender Therapy and Comparative Criminology 62(9): 2650-2668.

Cunneen C (2017) Arguments for raising the minimum age of criminal responsibility. Sydney, Australia: University of New South Wales.

Deitch M, Breeden R and Weingarten R (2012) Seventeen, going on eighteen: An operational and fiscal analysis of a proposal to raise the age of juvenile jurisdiction in Texas. American Journal of Criminal Law 40(1): 1-67.

Denver M (2017) Evaluating the impact of "old" criminal conviction decision guidelines on subsequent employment and arrest outcomes. Journal of Research in Crime and Delinquency 54(3): 379-408.

Eastwood J, Snook B and Luther K (2015) Measuring the reading complexity and oral comprehension of Canadian youth waiver forms. Crime \& Delinquency 61(6): 798828.

Ellis T and Kyo A (2017) Youth justice in Japan. In: Tonry M (ed.), Oxford handbook of crime and criminal justice online. Oxford, UK: Oxford University Press.

Farrington D P, Loeber R and Howell J C (2012) Young adult offenders: The need for more effective legislative options and justice proceedings. Criminology \& Public Policy 11(4): 729-750.

Farrington D P, Loeber R and Howell J C (2017) Increasing the minimum age for adult court: Is it desirable, and what are the effects? Criminology \& Public Policy 16(1): 83-92. 
Feld B C (2018) Punishing kids in juvenile and criminal courts. Crime \& Justice 47(1): 417474.

Fenwick M (2013) 'Penal populism’ and penological change in contemporary Japan. Theoretical Criminology 17(2): 215-231.

Foote D H (1992) The benevolent paternalism of Japanese criminal justice. California law review 80(2): 317-390.

Forst M and Fagan J (1989) Youth in prisons and training schools: Perceptions and consequences of the treatment-custody dichotomy. Juvenile \& Family Court Journal 40(1): 1-14.

Fowler E and Kurlychek M C (2018) Drawing the line: Empirical recidivism results from a natural experiment raising the age of criminal responsibility. Youth Violence and Juvenile Justice 16(3): 263-278.

Goldson B (2013) 'Unsafe, unjust and harmful to wider society': Grounds for raising the minimum age of criminal responsibility in England and Wales. Youth Justice 13(2): 111-130.

Goto H (2015) Seijinnenrei no hikisage. Hogaku Kyoshitsu 423: 30-35 (in Japanese).

Grisso T (1981) Juveniles' waiver of rights: Legal and psychological competence. New York, NY: Plenum Press.

Grisso T, Steinberg L, Woolard J, Cauffman E, Scott E, Graham S, Lexcen F, Reppucci N D and Schwartz R (2003) Juveniles' competence to stand trial: A comparison of adolescents' and adults' capacities as trial defendants. Law and Human Behavior 27(4): 333-363.

Hahn R, McGowan A, Liberman A, Crosby A, Fullilove M, Johnson R, Moscicki E, Price L, Snyder S, Tuma F, Lowy J, Briss P, Cory S and Stone G (2007) Effects on violence of laws and policies facilitating the transfer of youth from the juvenile to the adult justice 
system: A report on recommendations of the task force on community preventive services. Morbidity and Mortality Weekly Report 56(9): 1-11.

Haines K and Case S (2018) The future of youth justice. Youth Justice 18(2): 131-148.

Hamai K and Ellis T (2008) Japanese criminal justice: Was reintegrative shaming a chimera? Punishment \& Society 10(1): 25-46.

Hebenton B and Jou S (2010) Criminology in and of China: Discipline and power. Journal of Contemporary Criminal Justice 26(1): 7-19.

Henrichson C and Levshin V (2011) Cost-benefit analysis of raising the age of juvenile jurisdiction in North Carolina. New York, NY: Vera Institute of Justice.

Hoffmann J L (2007) Globarization and Japanese criminal law. In: Foote D H (ed.), Law in Japan: A turning point. Seattle, WA: University of Washington Press, 334-342.

Homusogokenkyujo (2007) Kenkyubuhokoku 35 - judaijihanshonen no jittai to shogu (dai 2 hokoku) -. Tokyo, Japan: Japanese Ministry of Justice.

Hornby Zeller Associates (2018) The cost of raising the age of juvenile justice in Michigan:

Final report: State of Michigan Legislative Council Criminal Justice Policy Commission.

Hoseishingikai (2018) Shonenho • keijiho (shonennenrei • hanzaisyashogukankei)bukai dail1kaikaigi. Tokyo, Japan: Japanese Ministry of Justice (in Japanese).

Illinois Juvenile Justice Commission (2013) Raising the age of juvenile court jurisdiction: The future of 17-year-olds in Illinois' justice system. Chicago, IL: Illinois Juvenile Justice Commission.

Independent Democratic Conference (2016) The price of juvenile justice: Why raising the age makes cents for New York. New York, NY: Independent Democratic Conference. 
Japan Federation of Bar Associations. (2015). Shonenho no 'seijin' nenreihikisage nikansuru ikensyo (in Japanese). Accessed 22 November, 2018, from https://www.nichibenren.or.jp/activity/document/opinion/year/2015/150220_2.html Japan Federation of Bar Associations. (2018). Shonenho niokeru 'shonen' no nenrei wo 18saimiman tosurukotoni hantaisuru ikensyo (in Japanese). Accessed 22 November, 2018 , from https://www.nichibenren.or.jp/activity/document/opinion/year/2018/181121_3.html Japan Federation of Bar Associations. (2019). Shonenho no tekiyonenreihikisage ni hantaishi, shodantaito to renkeishite korenitorikumu ketugi (in Japanese). Accessed 15 June, 2019 , from https://www.nichibenren.or.jp/activity/document/assembly_resolution/year/2019/2019 _2.html?fbclid=IwAR0h7E_c6979L3hb3tPz0O_DameeVYAOKfbudKnMbkJOlMlkj 6aFFoerr94

Japanese Criminal Law Scholars. (2015). Shonenho tekiyoutaisyonerei no hikisage ni hantaisuru keijihokenkyusha no seimei (in Japanese). Accessed 22 November, 2018, from https://sites.google.com/site/juvenilelaw2015/

Japanese Criminal Law Scholars. (2018). Shonen ho no jogen tonaru nenrei wo hikisagerutameno hokaisei wo okonaukotoni hantaisuru keijihokenkyusha no seimei (in Japanese). Accessed 22 November, 2018, from https://sites.google.com/view/juvenilelaw2018/\%E8\%A6\%81\%E6\%97\%A8?authuser $=0$

Japanese Ministry of Justice (2016) 'Jakunensya nitaisuru keijihosei no arikata nikansuru benkyokai': Torimatome hokokusho. Tokyo, Japan: Japanese Ministry of Justice (in Japanese). 
Jensen E L and Metsger L K (1994) A test of the deterrent effect of legislative waiver on violent juvenile crime. Crime \& Delinquency 40(1): 96-104.

Justice Policy Institute (2017) Raise the age: Shifting to a safer and more effective juvenile justice system. Washington, D.C.: Justice Policy Institute.

Kawade T (2015) Shonenho no tekiyonenreihikisage wo meguru giron. Keijiho Janaru 46: 3 (in Japanese).

Konishi T (2013) Diversity witin an Asian country: Japanese criminal justice and criminology. In: Liu J, Hebenton B and Jou S (eds.) Handbook of asian criminology. New York, NY: Springer, 213-222.

Kupchik A (2007) The correctional experiences of youth in adult and juvenile prisons. Justice Quarterly 24(2): 247-270.

Kuzuno H (2005) Juvenile diversion and the get-tough movement in Japan. Ryukoku Law Review 22: 1-21.

Loeber R, Hoeve M, Farrington D P, Howell J C, Slot N W and van der Laan P H (2012) Overview, conclusions, and policy and research recommendations. In: Loeber R, Hoeve M, Slot N W and van der Laan P H (eds.) Persisters and desisters in crime from adolescence into adulthood. Surrey, UK: Ashgate, 335-412.

Loeffler C E and Chalfin A (2017) Estimating the crime effects of raising the age of majority: Evidence from Connecticut. Criminology \& Public Policy 16(1): 45-71.

Loeffler C E and Grunwald B (2015) Decriminalizing delinquency: The effect of raising the age of majority on juvenile recidivism. Journal of Legal Studies 44(2): 361-388.

Loomis-Gustafson C (2017) Adjusting the bright-line age of accountability within the criminal justice system: Raising the age of majority to age 21 based on the conclusions of scientific studies regarding neurological development and culpability of young-adult offenders. Duquesne Law Review 55(1): 221-246. 
Louisiana Youth Justice Coalition (2016) A common-sense plan for safer communities: Include 17-year-olds in juvenile court. Baton Rouge, LA: Louisiana Youth Justice Coalition.

Lount S A, Hand L, Purdy S C and France A (2018) Tough talk: Youth offenders' perceptions of communicating in the youth justice system in New Zealand. Australian \& New Zealand Journal of Criminology 51(4): 593-618.

Maruyama M (2017) Shonenhotekiyonenrei no hikisagehihan. Meijo Hogaku 67: 123-151 (in Japanese).

Matsui S (2011) Justice for the accused or justice for victims? The protection of victims' rights in Japan. Asian-Pacific Law \& Policy Journal 13(1): 54-95.

McDiarmid C (2013) An age of complexity: Children and criminal responsibility in law. Youth Justice 13(2): 145-160.

McGowan A, Hahn R, Liberman A, Crosby A, Fullilove M, Johnson R, Moscicki E, Price L, Snyder S, Tuma F, Lowy J, Briss P, Cory S and Stone G (2007) Effects on violence of laws and policies facilitating the transfer of juveniles from the juvenile justice system to the adult justice system. American Journal of Preventive Medicine 32(4): 7-28.

Miyazawa S (2008) The politics of increasing punitiveness and the rising populism in Japanese criminal justice policy. Punishment \& Society 10(1): 47-77.

Modecki K L (2008) Addressing gaps in the maturity of judgment literature: Age differences and delinquency. Law and Human Behavior 32(1): 78-91.

Moriya K (2018) Shonenho kaisei no rekishi to nenreihikisage. Horitsujiho 90(4): 4-9 (in Japanese).

Murrie D C, Henderson C E, Vincent G M, Rockett J L and Mundt C (2009) Psychiatric symptoms among juveniles incarcerated in adult prison. Psychiatric Services 60(8): 1092-1097. 
National Prison Rape Elimination Commission (2009) National prison rape elimination commission report. Washington D.C.: National Prison Rape Elimination Commission.

Ng I Y H, Sarri R C, Shook J J and Stoffregen E (2012) Comparison of correctional services for youth incarcerated in adult and juvenile facilities in Michigan. The Prison Journal 92(4): 460-483.

Ng I Y H, Shen X, Sim H, Sarri R C, Stoffregen E and Shook J J (2011) Incarcerating juveniles in adult prisons as a factor in depression. Criminal Behaviour and Mental Health 21(1): 21-34.

Osaki Y (2017) Wagakuni niokeru shohensihoseido no genjo to shonenho tekiyonenrei no hikisage nikansuru kadai. Refarensu 67(10): 1-28 (in Japanese).

Otsuka E (2018) Shonenhotekiyojogennenrei no hikisage: Shinken no rikai to hikosHonen no tokusei no sitenkara. Kyoiku Gabanansu Kenkyu 1: 59-66 (in Japanese).

Prior D, Farrow K, Hughes N, Kelly G, Manders G, White S and Wilkinson B (2011) Maturity, young adults and criminal justice: A literature review. Birmingham, UK: Institute of Applied Social Studies, School of Social Policy, University of Birmingham.

Pruin I and Dünkel F (2015) Better in Europe? European responses to young adult offending: Full report. London, UK: Barrow Cadbury Trust.

Raise the Age NY. (n.d.). Accessed November 24, 2018, from http://raisetheageny.com/ Redding R E (2008) Juvenile transfer laws: An effective deterrent to delinquency? Washington D.C.: U.S. Department of Justice.

Risler E A, Sweatman T and Nackerud L (1998) Evaluating the Georgia legislative waiver's effectiveness in deterring juvenile crime. Research on Social Work Practice 8(6): $657-667$. 
Ryan T (2005) Creating 'problem kids': Juvenile crime in Japan and revisions to the juvenile act. AnJel Journal of Japanese Law 19: 153-188.

Saito T (2018) Shonenho no nenreihikisage no rekishitekisuimyaku. Kikan Keijibengo 93: 142-146 (in Japanese).

Sasaki M (2016) Shonenho 'tekiyonenreihikisage' mondai to kodomo no kenrihosyo. Kodomo no Kenri Kenkyu 27: 36-46 (in Japanese).

Schwarzenegger C (2003) The debate about the reform of the juvenile law in Japan. In:

Foljanty-Jost G (ed.), Juvenile delinquency in Japan: Reconsidering the "crisis". Leiden, Netherlands: Brill, 173-198.

Sharlein J (2018) Beyond recidivism: Investigating comparative educational and employment outcomes for adolescents in the juvenile and criminal justice systems. Crime \& Delinquency 64(1): 26-52.

Singer S I and McDowall D (1988) Criminalizing delinquency: The deterrent effects of the New York juvenile offender law. Law \& Society Review 22(3): 521-535.

Steinberg L (2008) A social neuroscience perspective on adolescent risk-taking. Developmental Review 28(1): 78-106.

Steinberg L, Albert D, Cauffman E, Banich M, Graham S and Woolard J (2008) Age differences in sensation seeking and impulsivity as indexed by behavior and selfreport: Evidence for a dual systems model. Developmental psychology 44(6): 17641778.

Steinberg L and Cauffman E (1996) Maturity of judgment in adolescence: Psychosocial factors in adolescent decision making. Law and Human Behavior 20(3): 249-272.

Steiner B, Hemmens C and Bell V (2006) Legislative waiver reconsidered: General deterrent effects of statutory exclusion laws enacted post-1979. Justice Quarterly 23(1): 34-59. 
Suzuki M and Otani A (2017) Myths of restorative features in the Japanese justice system and society: The role of apology, compensation and confession, and application of reintegrative shaming. Restorative Justice 5(2): 158-177.

Suzuki M, Pai C-F and Islam M J (2018) Systematic quantitative literature review on criminological theories in Asia. Asian Journal of Criminology 3(2): 129-151.

Takeuchi K (2015a) Shonenhotekiyonenrei ha hikisagerarerubekika. Jiyu to Seigi 60(10): 1116 (in Japanese).

Takeuchi k (2015b) Shonenhotekiyonenrei no hikisage. Horitsu Jiho 87(22): 1-3 (in Japanese).

Takeuchi K (2017a) Kenjiho karano kento: Shonenho no tekiyonenreihikisage no giron to 18saisenkyoken tono kankei. Hogaku Semina 744: 21-26 (in Japanese).

Takeuchi K (2017b) Shonenho nichidokuhikaku: 'Tekiyonenreihikisage' nitsuite kangaeru. Sekai no Jido to Bosei 81: 64-68 (in Japanese).

Takumi M (2017) Shonenho no tekiyonenrei hikisage wo meguru giron. Chosa to Joho 963: 1-14 (in Japanese).

Taylor M (2015) Juvenile transfers to adult court: An examination of the long-term outcomes of transferred and non-transferred juveniles. Juvenile and Family Court Journal 66(4): 29-47.

The Japanese Society of Psychiatry and Neurology. (2019). Shonenho"kaisei" nikansuru seimei (in Japanese). Accessed 15 June, 2019, from https://www.jspn.or.jp/uploads/uploads/files/activity/20190611.pdf

Thomas J (2017) Raising the bar: State trends: In keeping youth out of adults courts (20152017). Washington D.C.: Campaign for Youth Justice. 
Viljoen J L, McLachlan K, Wingrove T and Penner E (2010) Defense attorneys' concerns about the competence of adolescent defendants. Behavioral Sciences and the Law 28(5): 630-646.

Washington State Institute for Public Policy (2014) The effectiveness of declining juvenile court jurisdiction of youth. Washington D.C.: Washington State Institute for Public Policy.

Washino K (2017) Kindaisyonenhosei niokeru miseinennenrei: Kyukeihojidai kara syowasyonenhouseitei made. Hikakuhosei Kenkyu 40: 35-69.

Williams R (2015) Raising the age of juvenile court jurisdiction. LegisBrief 23(39): 1-2.

Yoshida T (2003) The future of the Japanese criminal justice system. In: Walgrave L (ed.), Repositioning restorative justice. Devon, UK: Willan Publishing, 328-338.

Zane S N, Welsh B C and Mears D P (2016) Juvenile transfer and the specific deterrence hypothesis: Systematic review and meta-analysis. Criminology \& Public Policy 15(3): 901-925.

Zelle H, Romaine C L R and Goldstein N E S (2015) Juveniles' Miranda comprehension: Understanding, appreciation, and totality of circumstances factors. Law and Human Behavior 39(3): 281-293. 